\title{
Price and Pretense in the Baby Market
}

\section{Kimberly D. Krawiec}

Few proposals generate the moral outrage engendered by a suggestion that babies - or, more accurately but less vividly, parental rights - should be traded on the open market. More than anything else, baby selling seems to fly in the face of our deeply held convictions that some items are too priceless to ever be bought and sold. Throughout the world, in fact, baby selling is formally prohibited. And throughout the world babies are bought and sold each day. As demonstrated in this Essay, the legal baby trade is a global market in which prospective parents pay, scores of intermediaries profit, and the demand for children is clearly differentiated by age, race, special needs, and other consumer preferences, with prices ranging from zero to over one hundred thousand dollars.

Yet legal regimes and policymakers around the world pretend that the baby market does not exist, most notably through proscriptions against "baby selling" typically defined as a prohibition against the relinquishment of parental rights in exchange for compensation. As a result, fees, donations, and reimbursements take the place of purchase prices. Although large sums of money change hands and many market intermediaries profit handsomely from the baby trade, compensation to some of society's most vulnerable suppliers is legally restricted and, despite the successful addition of new sources of supply, the number of available "desirable" children continues to fall far short of demand.

\footnotetext{
Professor of Law, University of North Carolina. Email: krawiec@email.unc.edu. For helpful comments on earlier drafts, I thank Scott Baker, Mary Ann Case, Andrew Chin, Adrienne Davis, Maxine Eichner, Adam Feibelman, Mitu Gulati, David Hyman, Melissa Jacoby, Julia Mahoney, Hiroshi Motomura, Eric Muller, Elizabth Scott, Mark Weisburd, workshop participants at the Universitities of Alabama, North Carolina, Illinois, Vanderbilt, and Washington \& Lee law schools, and roundtable participants at Baby Markets: Money, Morals, and the Neopolitics of Choice.
} 
Until recently, the most visible and contested debates regarding baby markets primarily addressed the normative desirability of an open-market baby exchange, largely assuming that formal bans against baby selling relegated the baby trade to the black and gray markets. (Landes \& Posner 1978; Radin 1996; Anderson 1993) Recent analyses, however, persuasively document the legal, but highly imperfect, baby market, rendering (in some circles, at least) assertions regarding the existence of legal baby markets so widely accepted as to be almost mundane. (Spar 2006; Goodwin 2006; Sanger 2006; Ertman 2003).

This Essay explores the costs of societal pretense that legal baby markets do not exist. Those costs include scarcity, forgone opportunities to address market failures, an inability to develop regulations designed to further particular public policies unlikely to be advanced solely through the goal of profit-maximization, and the promotion of rentseeking. This Essay focuses specifically on the rent-seeking problem, arguing that, although frequently defended by those who contend that commercial markets in parental rights commodify human beings, compromise individual dignity, or jeopardize fundamental values, bans against baby selling (at least as currently written and enforced) serve little purpose other than enabling anti-competitive behavior by the most economically and politically powerful baby market participants.

Part I of this essay defines the baby market, demonstrating both its similarities to and differences from other types of commercial markets. Part II argues that a systematic failure to acknowledge the full depth and breadth of the baby market extracts a high price from the market and its participants. That price includes forgone opportunities to improve market functioning, as discussed in Part II.A., and an inability to address 
potential tensions between public policy and collective action concerns, on the one hand, and market forces and individual choice, on the other hand, as discussed in Part II.B. Part III, however, addresses the highest price imposed by legal pretense regarding baby markets - a romanticization of the baby market and its distribution networks enables politically and economically powerful market participants to cloak private wealth transfers as public-interested regulation. Part IV concludes.

\section{DEFINING THE MARKET}

To say that a baby market exists, of course, indicates relatively little about that market, either normatively or descriptively. As a descriptive matter, the baby market resembles other common markets in some ways and not in others. As a normative matter, the baby market poses many of the standard regulatory concerns presented by other commercial markets, including issues arising from unequal bargaining power or access to information, such as fraud; anti-competitive behavior, such as price-fixing and barriers to market entry; and collective action problems, such as the "race to the courthouse" in bankruptcy. Yet the important public policy issues raised by trafficking in human lives suggest that the baby market raises special regulatory concerns as well. Understanding these similarities to, and differences from, other markets - along with the baby market's unusual political dimensions - provides insight into the regulatory concerns raised by the baby market.

\section{A. Common Market Attributes: Industry Segmentation and Price Differentiation}


Like many other markets, the baby trade can be divided into distinct market sectors. A robust and growing commercial market exists in each of these sectors, including the $\$ 3$ billion assisted reproductive technology (ART) industry; the "donation" of sperm and eggs for prices ranging from under one hundred to over one hundred thousand dollars; the controversial, but growing, surrogacy industry; and the adoption market, including the highly commercial international and private domestic adoption sectors. (Spar 2005; Krawiec 2009a)

Although the product supplied in each sector of the baby market differs - ranging from the hope of a future child in the ART sector to a fully-formed, already existing child in the adoption sector - effective regulation of the baby trade necessitates a unified, holistic approach to the market. This is not to imply that a one-size-fits-all legal regime is suitable for the varied sectors of the baby market. To the contrary, each market sector poses vastly different legal and public policy issues. (c.f. Krawiec, 2009a)

But because each industry sector can act as an imperfect substitute for the others, regulation that limits supply in one sector will channel consumers into another. In other words, prospective parents determined to have a child may be forced into the next best substitute, say adoption, when their first reproductive choice, say ART, has been fully exhausted without success or becomes otherwise unavailable. As a result, regulations and market failures that limit the egg trade will force prospective parents into the adoption market, and vice versa. (c.f. Bartholet, pp. 9-10) Moreover, a holistic approach to the baby market that encompasses each of its various sectors facilitates an analysis of an important commonality across those sectors - the extent to which societal pretense 
regarding the existence of for-profit market exchange obscures anti-competitive behavior by economically and politically powerful baby market participants.

A second point of commonality between baby markets and traditional commercial markets is price-differentiation based on consumer preferences. The extent of this price differentiation depends on the particular baby industry sector in question. Although some baby market sectors exhibit relatively low levels of price differentiation based on perceived quality, others exhibit enormous variation. In the gestational surrogacy market, for example, the surrogate bears no genetic relation to the child. Intended parents, therefore, have relatively basic requirements, such as the surrogate's willingness to live a healthy lifestyle and the probability that she will relinquish the child at birth. As a result, although there is some price differentiation, gestational surrogacy compensation tends to vary within a relatively narrow range within specific geographic markets.

Egg market pricing, in contrast, is highly differentiated according to the perceived genetic quality and traits of the egg "donor." As the market has become more commercial, the demand for particular genetic preferences has increased. Although the base-line rate for eggs in 1999 was $\$ 2,500$ to $\$ 5000$, depending on geographic region, donors with traits that are particularly rare or desired command significantly higher prices. (American Society of Reproductive Medicine 2000) For example, East Asian and Jewish eggs command a price premium, because they are rarer, as do the eggs of Ivy League college students, women with high SAT scores, women with athletic ability, and women with extraordinary physical attractiveness. (Krawiec 2009a)

Similarly, the adoption sector is price differentiated based on race, age, special needs, and other consumer preferences. Minority, older, and special needs children can 
be adopted from the foster care system for prices ranging from zero to $\$ 2500$, thanks to a variety of federal and state adoption assistance and subsidies. The healthy, white infants acquired through private agency and independent adoption, by contrast, typically command placement fees ranging from $\$ 10,000$ to $\$ 40,000$, although prices as high as $\$ 100,000$ have been reported. (Spar, 178-79) In addition, adoptive parents of these children frequently must pay birth parent expenses, including medical and living costs, legal representation, and counseling. (Evan B. Donaldson Adoption Institute, Costs of Adoption)

In the international adoption market, prospective parents can select children from thirty-nine different countries, each of which provides a different product and price structure. For example, in China, the available children are almost exclusively girls, generally between the ages of ten and seventeen months. Although Russia has both boys and girls available, there is a much larger supply of older children than of infants, which are in short supply and costly. In Guatemala, the children are generally very young, and of Mayan decent. Choosing a country, therefore, involves choosing your child's race, age, and other characteristics, with prices varying accordingly. (Spar 2005)

In summary, the exchange of parental rights operates in many ways like any other market. Despite formal bans on baby selling, in the United States alone in 2001, roughly 41,000 children were born through assisted reproduction, 6000 of whom were created through the use of "donated" eggs, and 600 of whom were carried by surrogates. (Spar p. IX) In 2003, Americans adopted 21,616 children through international adoptions, and gave birth to 30,000 babies using commercially purchased sperm. (Spar p. X) Each of these children was purchased, usually at great cost. 


\section{B. Distinct Market Attributes: Public Policy, Inelasticity, Substitutability, and Consumer Desperation}

The baby market differs from many other commercial markets in important ways, however. First, and most obviously, the fact that the "product" in question is a human being (or future being) raises difficult public policy issues not implicated by commercial exchange in other markets. The baby market can, and should, never be identical to the markets for bonds, cars, or pets, and nothing in this essay is intended to suggest otherwise. Nor do I mean to suggest that other regulatory goals should take precedence over the best interests of the children and future children traded in this market. Yet, as elaborated in the section and elsewhere (Krawiec, 2009a), societal pretense regarding the existence of legal baby markets is not a necessary component of a legal regime that holds the best interests of children paramount. Indeed, the contrary is true: pretense regarding legal baby markets thwarts the development of sound public policies designed to protect the best interests of children.

Second, the baby market exhibits the characteristics of a market in which demand is inelastic with respect to price. ${ }^{2}$ Demand in the baby market often knows no limits. For some prospective parents, the desire for a family is so strong that they will stop at virtually nothing to procure a child - they will take on a second job, mortgage their house, incur massive debt, deplete their savings account, and sell other assets. In short, attempts to acquire a child often stop only when success is attained or access to funds

\footnotetext{
${ }^{2}$ The price elasticity of demand is "the percentage change in the quantity of a good demanded that results from a one percent change in price," but is rarely constant across all ranges of demand and price. (Frank 1999, p.122.) Demand for a good is said to be elastic with respect to price if price elasticity is less than -1 , and inelastic if price elasticity is between -1 and zero. A variety of factors impact the price elasticity of demand, including: the availability of substitutes, the product's share of total expenditures, and the effect of income. (Frank, pp. 130-31) Other commonly-invoked examples of markets in which demand is inelastic with respect to price include addictive and life-saving drugs. (Tewari \& Singh, p. 44; Ringel, p. 36)
} 
runs out. Although demand in the baby market is not completely price insensitive (customers do care about price and do purchase fewer services when prices rise), "frequently, people buy on hope rather than on performance, and they base their spending largely on their available resources." (Spar, p. 32)

Third, and relatedly, for three reasons elaborated here, the role of substitutes is tricky in the baby market, reducing the downward price pressure created by close substitutions in many other markets. First, other markets supply no suitable substitute products. For most prospective parents, a puppy is not an acceptable substitute for a baby.

Second, the baby market exhibits significant product differentiation across its various industry sectors. As previously discussed in Part I.A., prospective parents may be forced into a second-best reproductive option when their first reproductive choice is foreclosed. Yet such forced substitutions do not diminish the extent of product differentiation in the baby market. For example, although some parents are indifferent as between the choice of genetic offspring and an adoptive child, others will turn to substitutes only when all hope of a genetic heir to one or both parents has run out.

Third, within most baby market sectors (gestational surrogacy, as previously noted, being a possible exception) babies and baby-making components tend to be highly differentiated, even within an industry segment. Parents desiring a healthy infant, for example, are unlikely to accept an older or special needs child, absent extraordinary circumstances. Similarly, many parents desire - and are willing to pay a premium for $-\mathrm{a}$ child matching their own ethnic background. 
Commentators frequently consider the level of product differentiation in analyzing market regulation, because the unwillingness of consumers to switch to a competitor's product reduces the incentives for sellers to compete on price. As a result, product differentiation increases the market power of individual sellers and can result in higher consumer prices. (Viscusi, et. al., 109-112; Hovenkamp, 37). At the same time, however, product differentiation may thwart some types of producer collusion, by complicating the ability to set prices. (Hovenkamp, 37)

Finally, infertile couples understandably do not view themselves as purchasing a baby or, perhaps, even entering into a market transaction, and their behavior as consumers in the baby market tends to reflect this, differing from consumer behavior in other types of transactions. Prospective parents, for example, frequently do not engage in extensive price comparison or bargaining over fees; change providers only reluctantly, even when faced with a lack of success through a given provider; and behave like desperate parents, rather than rational consumers, when weighing their purchasing options. (Spar, p.49, p. 244, n. 42.) As discussed in Part II.B., these - and other -distinct features of the baby market suggest that, despite the baby market's many similarities to other commercial markets, it also poses unique regulatory issues that distinguish it from other markets.

\section{The Costs of Regulatory Pretense}

The failure to acknowledge the full breadth of the legal baby market imposes severe costs on the market and its participants. Those costs include the forgone 
opportunity to develop legal policies designed to improve the functioning of the market, as discussed in Part II.A., and forgone opportunities to further particular public policies unlikely to be advanced solely through the goal of profit-maximization, as discussed in Part II.B. This is not to suggest that legal oversight is a panacea without costs of its own. Greater government involvement means that costs are likely to rise, some services that people desire may be prohibited, and certain types of customers -- for example, older parents, single parents, and gay and lesbian parents - risk being legislated out of the market. These are the costs that must be weighed against attempts to improve the baby market.

The primary focus of this Essay, however, as discussed in Part III, is not the forgone opportunity for the development of sound legal policies, but a failure to properly understand the purpose and effect of existing legal rules. Specifically, the romanticization of the baby market and a failure to understand its market participants and distribution networks enables economically and politically powerful market actors to extract private benefits from the state under the guise of public interest regulation.

\section{A. Improving Market Functioning}

A regulatory failure to recognize markets as markets may prevent those markets from operating at their full potential. As detailed in Part III, for example, the regulatory exclusion of many suppliers form the substantial profits shared by other baby market participants reduces the available supply. 
Moreover, microeconomic theorists have identified a variety of conditions necessary to the competitive functioning of markets, and regulatory regimes governing other commercial markets frequently seek to promote those conditions. For example, the legal regime may seek to reduce transaction costs, information asymmetries, externalities, monopolies, and barriers to the provision of public goods. (Kreps, 193-95, 202-04, 26365; Knight, 9-13). Towards those ends, some commentators have advocated disclosurebased baby market regulations, such as those governing the securities markets (Goodwin). Others have looked to the markets for luxury goods, organs, or health care for regulatory guidance. (Spar, pp. 217-224) Societal pretense regarding the baby market's very existence, however, renders many such regulatory analogies politically impractical.

\section{B. Other Public Policies}

In addition to impeding the development of legal policies designed to ensure the efficient functioning of the market, the insistence on treating exchanges in an impersonal, profit-centered market as if they were motivated by something else - altruism or personal preference, for example - thwarts the development of legal rules designed to further particular public policies unlikely to be advanced solely through the goal of profitmaximization. Disparate access to the baby market, for example, implicates troubling issues of class and race that deserve - and largely fail to receive - the attention of commentators and policymakers. Common defenses of limitations on compensation to birth parents, surrogates, and egg donors, for example, rest on claims that a legalized 
baby market would convert poor and (particularly in the case of gestational surrogacy) minority women into handmaidens for their wealthier counterparts, and that a market pricing system would unambiguously highlight the extent to which Americans value black children less than white children. Yet this is the reality of the baby market as it currently exists: women of color act as surrogates for white women with increasing frequency, (Spar, pp. 82-83) rarely use ARTs to redress their infertility, (Roberts pp. 25064) and disproportionately face the involuntary termination of parental rights. ${ }^{3}$

Moreover, only those determinedly ignorant of the differentiated pricing in the adoption market could fail to appreciate the fact that Americans' preference for white children is already obvious.

At the same time, however, the anti-competitive capping of egg donor compensation and laws limiting birth parent compensation in the adoption market to reasonable living expenses primarily affects the earning power of egg donors and birth parents with the most highly valued genetic and other traits. In other words, legal pretense regarding baby markets in these industry sectors primarily harms women who are attractive, white (or, in the case of the egg market, of a particularly desired ethnic ancestry, such as east Asian or Jewish), and intelligent. (Krawiec, 2009a)

In addition, technological and other baby market innovations create a potential tension among public policy goals, market forces, reproductive freedom, and parental rights that troubles many baby market observers. For example, concerns over eugenics plague the sperm and egg sectors of the market, while differential access to, and the

\footnotetext{
${ }^{3}$ Extrapolating from the data available from the U.S. Department of Health and Human Services for 2001 on the children whose parents have had their parental rights terminated, and assuming a similar distribution among children in foster care and parents whose parental rights have been terminated, suggests that black (non-Hispanic) and white parents are represented roughly equally among parents with involuntarily terminated parental rights (37\% versus $38 \%$, respectively), despite the greater percentage of whites in the population. This extrapolation is necessary because, although statistics on children whose parents have had their parental rights terminated are readily available, information is not collected on the parents whose rights are terminated. Wiley, et. al., pp. $22-23$.
} 
potential uses of, PGD (pre-implantation genetic diagnosis) raise other important public policy issues. (Krawiec, 2009)

To illustrate, in the absence of universal access to PGD, poor mothers may be more likely to give birth to a child with a genetic disease than an affluent mother, who can afford to have her embryos screened. As a result, those families least able to afford the special needs of a child with a genetic disease may be most likely to give birth to such children. Moreover, because white women currently are more likely to use ARTs, including PGD, than are black women, if this trend continues genetic diseases may be disproportionately borne by racial minorities. (Roberts pp. 250-64; Genetics and Public Policy Center, 2005, pp. 9-10)

Other contested uses of PGD include embryo selection for a genetic match to an existing child so that the new child can be a stem cell donor; the use of PGD to screen embryos for adult-onset diseases, such as Alzheimer's; and screening for mutations indicative of a heightened, but uncertain, risk of some diseases, such as breast cancer. Finally, many disability advocates worry about the potential implication of PGD that individuals with disabilities - many of whom lead happy, productive lives - would have been better off never being born. (Hudson, pp. 1642-43)

Non-medical uses of PGD are even more contested. For example, gender selection is a quickly-growing and controversial use of PGD that is legal in the United States, but banned in most other countries. (Stein) In addition, although not currently scientifically possible, many scientists consider it "not completely implausible" that technology may someday enable parents to select other genetic advantages for their 
children - advantages that will accrue only to those who can afford PGD. (Hudson, p. 1642)

These and other issues posed by the baby market may pit market forces and individual choice against public policy and collective action concerns because, in the abstract, respondents report high levels of discomfort with many of these scientific and market advances, including embryo purchases and the creation of customized children that meet the specific genetic preferences of their parents. (Genetics \& Public Policy Institute, What America Thinks, p. 38) But on an individual basis, parents do exactly what parents have always done - spend whatever is necessary to endow their families with the advantages that money and modern technology can provide. As a result, many customers are willing to buy - and many suppliers are willing to sell - a girl to the family who, through natural means, has managed to produce only boys; a child that is the perfect donor match to a sibling dying from a fatal illness; and, if it becomes technologically possible, a child with straight hair, blue eyes, high SAT scores, or natural musical aptitude.

The point here is not to argue for or against any of these commercial possibilities. But recognizing the baby trade for what it is - a market driven by profits and in which supply will inevitably grow to meet demand - is essential to understanding the tensions raised by this industry.

\section{Baby Selling Bans as Rent Seeking}


As discussed in Part II, societal pretense regarding the baby market poses a price in the form of the lost opportunity for sound law-making. The greater price, however, may be that the romanticization of the baby market obscures the impact of existing laws dictating the allocation of parental rights. The most obvious incarnation of this regulatory pretense is the legal rule prohibiting baby selling, typically defined as a prohibition against the relinquishment of parental rights in exchange for compensation. Frequently defended by those who contend that commercial markets in parental rights commodify human beings, compromise individual dignity, or jeopardize fundamental values, such bans, in fact, have more in common with the rent-seeking by powerful market actors seen in other commercial markets than with normative statements about the sanctity of human life. ${ }^{4}$

The notion that the government's power to regulate may be used to provide private benefits by restricting market entry, policing cartels, and legitimizing price-fixing tactics is a phenomenon well documented in other industries. (Stigler 1975; Macey 1986; Macey 2006) In fact, Stigler argues that every industry with sufficient political power to harness the state's coercive machinery will seek to use that authority to: (1) control market entry by new competitors and (2) police cartels and price fixing agreements. ${ }^{5}$ (Stigler pp. 5-6, 1975)

Baby-selling restrictions arguably serve both of these goals. As discussed in this section, a wide array of fertility specialists, agents, brokers, facilitators, lawyers, and

\footnotetext{
${ }^{4}$ This Essay does not attempt to rehash the voluminous literature debating the expressive function of baby selling bans. Instead, I argue that, even assuming that baby selling bans provide some expressive benefit, such benefits are substantially diminished by the reality of legal baby markets. Moreover, such "expression" extracts a high price, by using the dialog of public interest to mask private wealth transfers from less powerful Baby Market Suppliers to more powerful Baby Market Intermediaries. See Krawiec (2009a) (discussing this at greater length.)

${ }^{5}$ Stigler also contends that industries with sufficient political power will seek state assistance in encouraging the production of complements and discouraging the production of substitutes. Stigler at 6 . As previously noted, the role of substitutes in the baby market is complicated.
} 
other middlemen (hereafter, "Baby Market Intermediaries") legally profit handsomely from the baby market. As public choice theory would predict, these Baby Market Intermediaries are more economically and politically powerful than those suppliers of babies and baby-making components whose market access is legally restricted. Not coincidentally, Baby Market Intermediaries also have agitated actively for legal and industry restrictions that impede the ability of birth parents, gestational surrogates, and egg donors (hereafter, "Baby Market Competitors") - quite literally, the "mom and pop" producers of this industry -- from collecting the market clearing price for their services, thus reducing competition and capping the price of their required inputs. ${ }^{6}$ Not surprisingly, then, supply in these sectors of the baby market frequently falls far short of demand.

\section{A. Controlling Market Entry}

As discussed in this Part III.A., baby selling restrictions, adoption regulation, and legal uncertainty regarding the enforceability and payment terms of surrogacy contracts complicate the ability of birth parents and surrogates to collect the market clearing price for their services. Such rules thus deter independent market entry, preserving the division of profits among established baby providers and enhancing the role of Baby Market Intermediaries (particularly incumbent intermediaries, who have already established market position and reputational capital.)

\footnotetext{
${ }^{6}$ For similar arguments in the context of organ markets, see e.g. Goodwin (2006); Mahoney (2000). For influential discussions of the relationship between organ selling restrictions and the organ shortage, see Cohen (1995), Hansmann (1989), and Epstein (1997), chs. 9-12.
} 
To illustrate, the adoption sector can be broadly divided into the international and domestic markets. The domestic market, in turn, has both a private component, through which nearly all healthy white infants available for adoption in the United States are placed, and a state-run (foster care) component, in which older, minority, and special needs children are disproportionately represented. ${ }^{7}$ Both the international sector and the private domestic sector are distinctly commercial. In the private domestic market, adoption agencies, brokers, and facilitators typically command placement fees ranging from $\$ 10,000$ to $\$ 40,000$, although prices as high as $\$ 100,000$ have been reported. (Spar at 178-79)

Similarly, the majority of international adoptions in the United States are carried out through licensed agencies, which, in most states, have few limits on the fees and expenses charged to prospective parents. The domestic charges in international adoptions typically include an application fee, a home study fee, and a program fee. Overseas charges include a required "donation" to the child's orphanage, and fees to the agency's facilitator, drivers, and interpreters. These charges vary by agency and home country. (Spar, pp. 176-86)

Finally, adoptive parents in international and private domestic adoptions frequently pay birth parent expenses, including medical and living costs, legal representation, and counseling. (Costs of Adoption). However, international law, as well as the laws of all fifty states, forbid payments to birth parents in exchange for the relinquishment of parental rights. (Spar, pp. 176-186)

\footnotetext{
${ }^{7}$ An estimated one-half to two-thirds of U.S.-born healthy, white infants are placed directly by birth parents with adoptive parents through the assistance of an intermediary, such as an attorney, doctor, clergy, or other facilitator. Private Domestic Adoption. Estimates vary because states are not required to report private domestic adoptions. Id. The remainder are placed through for-profit or non-profit adoption agencies that are licensed by the state. Id.
} 
A variety of murky - and manipulable - state statutes govern these adoptionrelated fees. Although no state permits "baby selling," few states specifically cap or otherwise restrict permissible payments for medical, living, and other expenses of birth parents, allowing some latitude to those eager to evade such restrictions. At the same time, because such payments must be justified as reasonable living or other expenses, the restriction does deter very large payments and acts as a de facto price-fixing agreement that may prevent particularly desirable birth parents from collecting the market clearing price for their services.

In addition, nearly all states ban finders' fees to intermediaries, but most permit reasonable payments to intermediaries for services rendered in connection with the child's placement. (Private Domestic Adoption) Although the level of control and oversight over intermediary fees can vary significantly across jurisdictions, few states impose specific limits on such fees, providing a similar latitude to those eager to evade the ban on finders' fees.

Baby Market Intermediaries in the adoption sector, such as state-licensed adoption agencies, long have sought to protect their market positions through active agitation for prohibitions against baby selling, with exceptions for their own activities. (Zelizer, pp. 169-207; Spar, pp. 166-171; Landes \& Posner, pp. 346-47) Those efforts have met with mixed success in restricting market entry by private agencies and brokers that enjoy the political support of lawmakers, whose constituents value the larger supply and shorter waiting times associated with private adoption. (Zelizer, pp. 196-207) These anti-competitive efforts, however, have been quite successful against birth parents 
desiring to profit from the baby trade, nearly all of whom are funneled into the baby trade through a Baby Market Intermediary, rather than as direct suppliers.

Finally, legal uncertainty regarding the enforceability of surrogacy contracts and the permissibility of surrogacy payment terms in many jurisdictions channels some parents into less risky sectors of the baby market, causes those that remain in the surrogacy sector to charge a risk premium for the surrogate's risk of non-performance, and enhances the role of intermediaries (particularly incumbent intermediaries) whose reputations and profits depend on the repeated delivery of surrogates who will perform under the terms of the contract. (Sanger) The effect of each of these outcomes is to stymie the direct provision of surrogacy services and deter independent market entry.

\section{B. Cartelization and Price Fixing}

As discussed in Part III.A., legal bans on baby-selling that prevent compensation to birth parents for the relinquishment of parental rights while permitting Baby Market Intermediaries free reign in setting placement fees and other expenses make independent entry into the baby market less attractive for many Baby Market Competitors, thus restricting market entry. Less obviously, as discussed in this Part III.B., the insistence that Baby Market Competitors are, and should be, motivated primarily by altruism rather than by profit enables explicit and implicit price-fixing by Baby Market Intermediaries seeking to cap the price of their inputs. This produces two related results: (1) inefficiently low supply and high consumer prices, and (2) distributional concerns 
stemming from the distorted division of profits between Baby Market Intermediary and Competitor.

When babies, eggs, or the use of a womb are characterized as donative or altruistic transfers from a Baby Market Competitor, rather than as inputs into the final product (a child) offered for sale by Baby Market Intermediaries, it is easy to overlook the fact that such intermediaries have an economic interest in artificially depressing the price of that input. Of course, capping input prices reduces the available supply for both Baby Market Intermediaries and consumers. As in the traditional oligopsony model, however, Baby Market Intermediaries accept reduced access to inputs in exchange for a lower purchase price. ${ }^{8}$ In other words, assuming that the marginal cost of any unit of a good is the price paid on all prior units, an oligopsonist will fail to purchase some units whose value to the oligopsonist exceeds their costs, in order to cap the purchase price of prior units. (Boal \& Ransom) As a consequence, oligopsony power (like oligopoly power) produces inefficient supply levels. (Hovenkamp, p.14; Boal \& Ransom) The end result, as seen in all sectors of the baby market, is product scarcity. More difficult to observe - but inherent in the oligopsony model - is the distorted division of profits between producer (Baby Market Competitor) and middleman (Baby Market Intermediary) produced by baby selling restrictions.

Confusion regarding the economic effects of monopsony markets has sometimes led courts and policymakers to conclude that monopsony is not a concern of anti-trust law, which seeks a goal of low consumer prices. (Balmoral; Kartell) Such an approach, however, incorrectly assumes that the savings from low input prices in a monopsony

\footnotetext{
${ }^{8}$ The phrase "monopsony," meaning a single buyer, was first coined by Joan Robinson (Robinson, p.215) Given that single-buyer models are unrealistic as applied to modern markets, economists instead employ models of oligopsony or "competitive monopsony," in which buyer market power persists despite competition among buyers. The phrase "oligopsony" refers to the market power of buyers and not their number, which need not be small. (Bhaskar, et. al. p. 156)
} 
market will be passed on to consumers. Instead, a monopsonist who sells into a competitive market will charge consumers the same price as a non-monopsonist, but will supply a lower amount of the good. In contrast, a monopsonist buyer who also enjoys monopoly (or cartel) power over consumers will sell to consumers at a higher price than a non-monopsonist. ${ }^{9}$ (Hovenkamp, pp. 14-15) Monopsony markets, therefore, never benefit consumers, and create a deadweight efficiency loss, as do monopoly markets, because some market actors engage in a second-choice transaction that produces less social value than their first choice. ${ }^{10}$ (Hovenkamp, pp. 19-20)

This intuition has been employed in a growing body of work in labor economics, which posits that - in contrast to competitive employment models that assume a mass exodus of employees if the employer cuts wages -- employers may enjoy significant market power over their workers in some cases. (Card \& Krueger, 1995; Card \& Krueger 2000; Manning; Neumark and Wascher, 2000) That market power may derive from a variety of sources, including employer differentiation, moving costs, job search costs, an inability of rival employers to absorb additional employees quickly, and - most relevant for the baby market - employer collusion. (Bhaksar, et. al., p. 160)

Although empirical research documents numerous examples of collusion attempts (both successful and unsuccessful) (Levenstein \& Suslow), cartels are, in fact, difficult to organize and even more difficult to maintain. Incentive problems encourage cheating among cartel members and the possibility of super-normal profits encourage new market entrants, who compete with and destabilize the existing cartel. (Stigler, 1971; Grossman, pp.1-4; Baumol \& Blinder, p. 294) Consequently, successful cartels must have a credible

\footnotetext{
${ }^{9}$ As noted in Part III.A., legal restrictions and uncertainties impose a variety of barriers to entering the baby market, creating market power among industry incumbents.

${ }^{10}$ A difficulty with antitrust analyses of monopsony markets, however, is distinguishing low input purchase prices stemming from monopsony, versus those stemming from reduced transaction costs or the elimination of upstream market power. Hovenkamp, p. 16.
} 
enforcement mechanism to punish defectors, and a mechanism for preventing new market entrants, who would eat up any cartel profits. (Stigler,1964;Grossman, p.2) Legal rules can - and in the case of baby markets do - decrease the private costs of cartel formation and enforcement, and of policing market entry. (Stigler, 1964; Tilton)

As previously discussed, baby selling restrictions perform this input capping function of the buyers' cartel in the adoption and surrogacy sectors of the baby market. In the egg industry, input price capping is accomplished instead through explicit price fixing agreements in the form of professional standards. (Krawiec, 2009b) Yet the anticompetitive nature of these agreements rarely elicits comment or controversy, perhaps because the persistent dialog of altruism and donation that characterizes the egg business distracts observers from the true nature of the industry.

For example, the ASRM Ethics Committee Report recommending caps for financial incentives to egg donors, together with the published list of egg donor agencies that have signed an agreement with the Society for Reproductive Technology (SART) agreeing to abide by the Committee's recommendations governing egg donor payments, closely resemble the same types of price fixing agreements that have been deemed per se illegal in other industries. (American Society for Reproductive Medicine 2000; ASRM, List of Egg Donor Agencies; Krawiec, 2009b) Similarly, fertility clinics and doctors would likely not be so forthcoming in discussing with the press their informal attempts to limit prices paid for eggs in the New York metropolitan area, if they were given a reason to fear the reactions of policymakers and the public. (Mahoney, p. 187; American Radioworks) 
Ironically, such legal rules and the anti-competitive behavior that they enable are frequently defended as a means of preventing the commodification and commercialization of human beings, womens' labor, or motherhood. (Radin 1996; Anderson 1993; Walzer 1983; Shanley 2001) As demonstrated, however, the costs of these rules are borne primarily by Baby Market Competitors, who are disproportionately young, female, and in financial need. ${ }^{11}$ The benefits, meanwhile, are disproportionately enjoyed by wealthier and more politically powerful Baby Market Intermediaries.

Similar arguments have been made regarding the perverse effects of the ban against unconscionable contracts (Epstein 1975), protective women's labor laws (Novkov 2001; Bernstein 2003), and laws and rhetoric opposing the commodification of women's, particularly poor women's, labor. (Case, Cahn 2001; Silbaugh 1996; Williams 2000)

\section{CONCLUSION}

Commentators and policy makers have spent much time romanticizing or ignoring the baby market, and fretting over an impending commercialization or commodification that, in fact, took place long ago. In today's legal regime, rules prohibiting baby selling have little to do with grand normative statements about sacred values and, instead, accomplish little more than impeding market access by baby producers.

Societal pretense regarding the baby market is exhibited most clearly by the ban against baby selling. As demonstrated in this Essay, this supposed ban merely prevents full compensation to certain suppliers and does not (and is not designed to) prevent

\footnotetext{
11 "Financial need" should not be interpreted as synonymous with poor, although some Baby Market Suppliers - for example, birth parents in the international adoption market - may be poor. But many egg donors, in contrast, are college students anxious to earn extra money to defray educational or other expenses. Krawiec, 2009a
} 
commercial transactions in children. Therein lies the harmful hypocrisy of baby selling "bans." Were Americans serious about its refusal to attach price tags to children, the law would ban all commercial transactions in babies, rather than merely restricting compensation to Baby Market Competitors.

But baby market critics should not delude themselves about either the probability or the costs of a real baby selling ban. First, a true baby market ban would entail high costs. As demonstrated by the experience of those countries that have eliminated commercial exchange in some sectors of the baby trade, were the United States successfully to prohibit commercial transactions in children, supply in the baby market would be even further reduced. (Krawiec, 2009a)

Second, banning the baby market is politically infeasible in the United States. Consumer demand is simply too strong and too deeply felt, and unlikely to be sated through substitutes outside of the baby market. In addition, baby market consumers and intermediaries are too economically and politically powerful, and have too much at stake in the baby market to permit its abandonment.

Perhaps, in the absence of a sufficient number of healthy, white, infants, prospective parents would be forced into the only sector of the baby trade that, sadly, does not suffer from a shortage of supply - the state-run foster care system, through which a disproportionate number of older, minority, and special needs children are available. Such substitutions arguably have positive effects, such as providing homes to children who otherwise would remain in state care, or altering American norms about what constitutes a desirable child. Cross-racial adoptions, however, are controversial for a variety of reasons, and many child advocates worry about promoting through scarcity 
the adoption of special needs children by parents who are ill-equipped to handle the challenges.

This Essay encourages the recognition of the baby trade for what it is - a market, with similarities to and differences from, other markets. As with other markets, the legal regime may seek to improve competitive conditions, and should be suspicious of attempts to use the state's power to extract private benefits under the guise of public-interest regulation. Trafficking in human lives, however, poses some public policy issues that may be best addressed by political forces, rather than by market ones. Pretending that legal baby markets don't exist accomplishes none of these objectives. 


\section{Bibliography}

American Radioworks, The Fertility Race, Part 10, "The Decision to Donate” $§ 3$, "Assessing the Risks" (available at http://americanradioworks.publicradio.org/features/fertility race/part10/section3.shtml).

American Society for Reproductive Medicine (ASRM) Ethics Committee, "Financial Incentives In Recruitment Of Oocyte Donors," 74 Fertility \& Sterility 216 (2000).

American Society for Reproductive Medicine (ASRM), "Egg Donor Agencies," available at http://www.asrm.org/Patients/eggdonor_agencies.pdf.

Anderson, Elizabeth. Value in Ethics and Economics. Cambridge: Harvard University Press, 1993.

Balmoral Cinema v. Allied Artists Pictures Corp., 885 F.2d 313 (6 ${ }^{\text {th }}$ Cir. 1989).

Bartholet, Elizabeth. "Beyond Biology: The Politics Of Adoption \& Reproduction," 2 Duke J. Gender L. \& Pol'y 5 (1995).

Baumol, William J. and Blinder, Alan S. Economics: Principles and Policy, $6^{\text {th }}$ Ed. Fort Worth: South-Western, 1994.

Bernstein, David E. “Lochner's Feminist Legacy,” 101 Mich. L. Rev. 2401 (2003).

Bhaskar, V., et. al. "Oligopsony and Monopsonistic Competition in Labor Markets," 16(2) J. Econ. Persp. 155 (2002).

Boal, William and Michael Ransom. "Monopsony in American Labor Markets," EH.Net Encyclopedia, Robert Whaples, ed., (available at, http://eh.net/encyclopedia/article/boal.monopsony).

Cahn, Naomi R., "The Coin of the Realm: Poverty and the Commodification of Gendered Labor," 5 J. Gender, Race, \& Justice 1 (2001)

Card, David E., and Alan B. Krueger. Myth and Measurement: The New Economics of the Minimum Wage. Princeton: Princeton University Press, 1995.

Card, David E., and Alan B. Krueger. "Minimum Wages and Employment: A Case Study of the Fast-Food Industry in New Jersey and Pennsylvania: Reply," 90 (5) American Economic Review 1397 (2000).

Case, Mary Anne, "Pets Or Meat," 80 Chi.-Kent L. Rev. 1129 (2005) 
Cohen, Lloyd R., "Increasing The Supply Of Transplant Organs: The Virtues Of A Futures Market," 58 Geo. Wash. L. Rev. 1 (1989).

Epstein, Richard, A. Mortal Peril: Our Inalienable Right to Health Care? Cambridge: Perseus Books, 1997.

Epstein, Richard A., "Unconscionability: A Critical Reappraisal,” 18 J.L. \& Econ. 293 (1975).

Ertman, Martha M. "What's Wrong with a Parenthood Market?" 82 N.C. L. Rev. 1 (2003).

Evan B. Donaldson Adoption Institute. Costs of Adoption. New York, NY: 2006, available at http://www.adoptioninstitute.org/research/costsadoption.php.

Evan B. Donaldson Adoption Institute. Private Domestic Adoption. New York, NY: 2006, available at http://www.adoptioninstitute.org/research/domesticadoption.php.

Frank, Robert. Microeconomics and Behavior. McGraw-Hill, 1999.

Genetics and Public Policy Center, IMAGN! Increasing Minority Awareness of Genetics Now! Washington, DC: 2005, available at http://www.dnapolicy.org/pub.reports.php?action=detail\&report id=11).

Goodwin, Michele. Black Markets: The Supply and Demand of Body Parts. New York: Cambridge University Press, 2006.

Goodwin, Michele. "The Free-Market Approach to Adoption: The Value of a Baby," 26 B. C. Third World L. J. 61 (2006).

Grossman, Peter Z. "Introduction: What Do We Mean By Cartel Success?", in How Cartels Endure and How they Fail, pp. 1-8. Northampton: 2004 (Grossman, Peter Z. ed.)

Hansmann, Henry. "The Economics and Ethics of Markets for Human Organs," $14 \mathrm{~J}$. Health Pol. Pol'y \& L. 57 (1989).

Hopkins, Jim. Egg Donor Business Booms On Campuses, USA Today 1A (March 16, 2006).

Hovenkamp, Herbert. Federal Antitrust Policy and the Law of Competition and Its Practice. St. Paul: West Publishing Co., 2005.

Hudson, Kathy L. "Preimplantation Genetic Diagnosis: Public Policy and Public Attitudes," 85 (6) Fertility and Sterility 1638 (2006). 
Kalfoglou, A., et. al.. Reproductive Genetic Testing: What America Thinks.

Washington, DC: Genetics and Public Policy Center, 2004, available at

http://www.dnapolicy.org/pub.reports.php?action=detail\&report_id=6).

Kartell v. Blue Shield (Mass.), 749 F2d 922 ( $1^{\text {st }}$ Cir. 1984), cert. denied, 471 U.S. 1029, 105 S.Ct. 2040 (1985).

Knight, Jack \& Johnson, James. "The Priority of Democracy: A Pragmatist Approach to Political-Economic Institutions and the Burden of Justification." $101 \mathrm{Am}$. Poli. Sci. Rev., 47-61 (2007).

Krawiec, Kimberly D. (a) "Altruism and Intermediation in the Market for Babies" (forthcoming 2009, Wash. \& Lee L. Rev).

Krawiec, Kimberly D. (b) "Sunny Samaritans \& Egomaniacs: Price-Fixing in the Gamete Market (forthcoming, 2009, L. \& Contemp. Probs.)

Kreps, David. A Course in Microeconomic Theory. Princeton: Princeton University Press, 1990.

Landes, Elisabeth M. \& Posner, Richard A., "The Economics of the Baby Shortage," 7 (2) J. Legal Studies 323 (1978).

Levenstein, Margaret C. \& Suslow, Valerie Y, "Studies of Cartel Stability: A Comparison of Methodological Approaches," in How Cartels Endure and How they Fail, pp. 9-50. Northampton: 2004 (Grossman, Peter Z. ed.)

Macey, Jonathan R., "Commercial Banking And Democracy: The Illusive Quest For Deregulation," 23 Yale J. on Reg. 1 (2006).

Macey, Jonathan R., "Promoting Public-Regarding Legislation Through Statutory Interpretation: An Interest Group Model”, 86 Colum. L. Rev. 223 (1986).

Mahoney, Julia D. “The Market For Human Tissue,” 86 Va. L. Rev. 163 (2000).

Manning, Alan. Monopsony in Motion: Imperfect Competition in Labour Markets Princeton: Princeton Univ. Press, 2003.

Neumark, David and William Wascher. "Minimum Wages and Employment: A Case Study of the Fast-Food Industry in New Jersey and Pennsylvania: Comment." 90 (5) Am. Econ. Rev. 1362 (2000).

Novkov, Julie. Constituting Workers, Protecting Women: Gender, Law, and Labor in the Progressive Era and New Deal Years. Ann Arbor: University of Michigan Press, 2001. 
Radin, Margaret Jane. Contested Commodities. Cambridge: Harvard University Press, 1996.

Ringel, Jeanne S., et. al., The Elasticity of Demand for Health Care. Santa Monica: RAND, 2002.

Roberts, Dorothy. Killing the Black Body: Race, Reproduction and the Meaning of Liberty. New York: Vintage Books, 1997.

Robinson, Joan. The Economics of Imperfect Competition London: Macmillan, 1933.

Sanger, Carol. "Developing Markets in Baby-making: In the Matter of Baby M." 30

Harv. J. L. \& Gender 67 (2007).

Shanley, Mary Lyndon. Making Babies, Making Families. Boston: Beacon Press, 2001.

Silbaugh, Katherine. "Turning Labor into Love: Housework and the Law," 91 Nw. U. L. Rev. 1 (1996).

Spar, Debora L. The Baby Business. Boston: Harvard Business School Press, 2006.

Stein, Rob. “A Boy for You, A Girl for Me,” Wash. Post A1 (Dec. 14, 2004).

Stigler, George J. "The Theory of Economic Regulation," 2 (2) Bell J. Econ. \& Mgmt. Science 3 (1971).

Stigler, George J. "A Theory of Oligopoly,” 72 J. Political Economy 44 (1964).

Tewari, D.D. \& Singh, Katar. Principles of Microeconomics. New Delhi: New Age International Limited Publishers, 1996.

Tilton, Mark. "The Difference Government Policy Makes: The Case of Japan," in How Cartels Endure and How they Fail, pp. 174-95. Northampton: 2004 (Grossman, Peter Z. ed.)

Viscusi, W. Kip, et. al. Economics of Regulation and Antitrust. Cambridge: MIT Press (3d ed. 2001).

Walzer, Michael. Spheres of Justice: A Defense of Pluralism and Equality. New York: Basic Books, 1983.

Wiley, Mary O'Leary \& Baden, Amanda L. "Birth Parents in Adoption: Research, Practice, and Counseling Psychology," 33 (1) The Counseling Psychologist 22-23 (2005).

Williams, Joan. Unbending Gender: Why Family and Work Conflict and What to Do About It. New York: Oxford University Press, 2000. 
Zelizer, Viviana A. Pricing the Priceless Child: The Changing Social Value of Children. Princeton: Princeton Univ. Press, 1985. 